\title{
イオン伝 導体と電極
}

\author{
松井昇 \\ (株)豊田中央研究所 昰480-11 愛知県愛知郡長久手町 \\ (1994 年 1 月 10 日受理)
}

\section{Ionic-Conductor and Electrode}

\author{
Noboru Matsui \\ Toyota Central R\&D Labs., Inc., Nagakute, Aichi 480-11
}

(Received January 10, 1994)

\begin{abstract}
固体デバイスの電荷担体は，多くの場合，電子かホールである。固体の中には，支配的な電荷担体が電子 やホールではなく, 電子の数干倍の質量をむつイオンであるイオン伝導体と呼ばれる物質がある。電荷担体 がイオンの場合に限らず, 電子やホールの系です電気的特性を調べるには電極が不可欠である。電極には, 系を乱さないで計測をするために工夫されたものから，積極的に電極反応を起てして，生成物やエネルギー を効率的に取り出すむのまでたくさんの種類がある。生体電極は前者, 電池は後者の代表例である。イオン 伝導を応用する系は，デバイス全体の構成が電子伝導体（電極）／イオン伝導体／電子伝導体（電極）とな る。この系は, 全体が電子伝導の系と比べ, 電極部での電荷担体のやりとりが異なるなど複雑で, 電極に求 められる機能む多岐にわたる。こてでは, 最初に電荷担体が電子 (ホール) とイオンの場合での電極機能の 違いを考える。つぎに，電荷担体がカチオン（陽イオン）のイオン伝導体（ $\beta$ - アルミナ）と，アニオン（陰 イオン）のイオン伝導体（定安化ジルコニア）の場合の電極挙動を比較して考える。安定化ジルコニアの系 については，さらに応用時の電極の問題について具体例で示す。
\end{abstract}

\section{1.はじめに}

固体の電気的特性を研究されている方々の大半は, 電 荷担体が電子の系を取り扱っています。固体の中には， このほかに支配的な電荷担体が電子やホールではなく, 電子の何千倍の質量をあつイオンである伝導体が見出さ れています。そしてイオン伝導性の高い物質は, 固体電解 質 (solid electrolyte) とか超イオン伝導体 (superionic conductor）と呼ばれ, 機能材料としてセンサ, 表示素 子および然料電池などへの応用が進められています。本 稿では以降, てれらの物質をイオン伝導体と呼ぶことに します。

イオン伝導体を用いるデバイスでは，電極の性能がと りわけ重要です。電子伝導の系を含めて, 電気的特性を 調べるには電極が不可欠です。電極には, 系を乱さない で計測するために工夫されたすのから, 積極的に電極反 応を起てし, 生成物やエネルギーを効率的に取り出すす のまでたくさんの種類があります。
溶液系の電気化学すイオンが関係する電極反応を取り 扱います。しかし，室温前後での反応を中心としたての 溶液系と, 高温を主とする固体系の間にあ取り扱い上の 相違点があります。厳密な取り扱いについては専門書を で参照いただくてとにして，乙てでは，二，三のイオン 伝導体について電極周辺の話題を取り上げながら, 電荷 担体が電子とイオンの場合の電極機能の違いなどを考え ます。

\section{2. イオン伝導体}

1930 年代に，ドイッで C. Wagner を中心とする一 派が高温系の固体化学の分野で多くの成果をあげまし た。そして 1950 年代後半になると, 当時, 赤熱させて 照明用フィラメントに使われていたジルコニア系酸化物 について, 電子の何千倍の質量をむつアニオン (anion: 陰イオン）が電荷担体であるてとを明らかにしました。

これを契機に，固体中のイオンの移動現象を取り披う 高温電気化学, あるいは固体電気化学と呼ばれる分野が 
表 1 イオン伝導体

\begin{tabular}{|c|c|c|c|}
\hline \multicolumn{2}{|r|}{ イオン伝導体 } & 電荷担体 & 応 用 例 \\
\hline \multirow{2}{*}{$\begin{array}{l}\text { ア型 } \\
= \\
\text { オ } \\
\text { ン }\end{array}$} & $\begin{array}{c}\text { 安定化ジルコニア } \\
\left(\mathrm{ZrO}_{2}-\mathrm{MnOm}\right)\end{array}$ & $\mathrm{O}^{2-}$ & $\begin{array}{l}\text { 酸素センサ } \\
\text { 然料電池 }\end{array}$ \\
\hline & $\mathrm{CaF}_{2}$ & $\mathrm{~F}^{-}$ & \\
\hline \multirow{4}{*}{$\begin{array}{c}カ \\
夭 \\
オ \\
\text { ン } \\
\text { 型 }\end{array}$} & 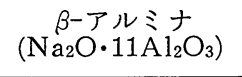 & $\mathrm{Na}^{+}$ & $\mathrm{Na}-\mathrm{S}$ 電池 \\
\hline & $\beta-A g l$ & $\mathrm{Ag}^{+}$ & \\
\hline & $\mathrm{Li}_{3} \mathrm{~N}$ & $\mathrm{Li}^{+}$ & \\
\hline & $\mathrm{HUO}_{2} \mathrm{PO}_{4} \cdot 4 \mathrm{H}_{2} \mathrm{O}$ & $\mathrm{H}^{+}$ & \\
\hline
\end{tabular}

急激に発展しました。こてでは，現在までに見出された 代表的なイオン伝導体を表 1 亿示すにとどめます。表中 のジルコニアは, 後で述べるように皆さんの身近で重要 な機能をもつデバイスに応用されています。

\section{3. イオン伝導体の電極}

\section{1 電子伝導体の電極との比較}

図 1 亿電荷担体が電子とイオンの系について，電極の 役割を示しました。乙の図で両者の電極に求められる機 能が異なることがおわかりいただけるかと思います。イ オン伝導体には, 表 1 のように電荷担体がアニオンとカ チオン (Cation: 陽イオン) のものがあります。図1 (b) に示したのはカチオン伝導体／電極（電子伝導体）系の 電荷担体の流れです。図 1 ( c c)にはアニオン伝導の場合 を示しました。

$\beta$-アルミナは, $300^{\circ} \mathrm{C}$ 前後で作動する $\mathrm{Na}-\mathrm{S}$ 電池の隔 壁に使われる優れたカチオン（ナトリウムイオン : $\mathrm{Na}^{+}$) 伝導体です。また，安定化ジルコニアは $1,000^{\circ} \mathrm{C}$ 近くで きわめて良好なアニオン（酸化物イオン: $\mathrm{O}^{2-}$ ) 伝導体 です。カチオン伝導体ではたいていの場合, 電荷担体に なるイオンと同じ元素の金属電極を用いるととができま す。特に図の例のナトリウム $\left(\mathrm{mp} \mathrm{:} \sim 98^{\circ} \mathrm{C}\right)$ は $300^{\circ} \mathrm{C}$ で 液体状態で，固体の $\beta$-アルミナとの界面は良好な接触 界面を形成します。乙の場合には，電極(電子伝導体)／ イオン伝導体界面での電子の授受（図中，カッコ内に示 した）が容易に行われます。一方，アニオン伝導体の場 合, 電荷担体の元素と異なる電極材料が使われる系も多 くあります。乙の種の系では，電極物質は電荷担体にな って移動することができません。図の例であ，白金は多 孔性薄膜にして, 電荷担体になる酸素分子が容易に移動 できるような構造にします。図の例からイオン伝導体と 電極の関係は，電子伝導体の系に比べ複雑なととがおわ かりいただけたと思います。つぎに，応用の最む進んだ 安定化ジルコニアに絞って, 電極周辺の話題を少し詳細
( a)

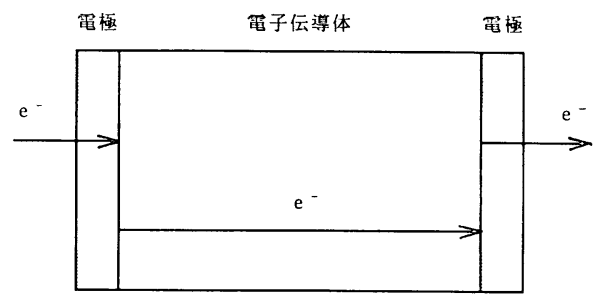

$(b)$

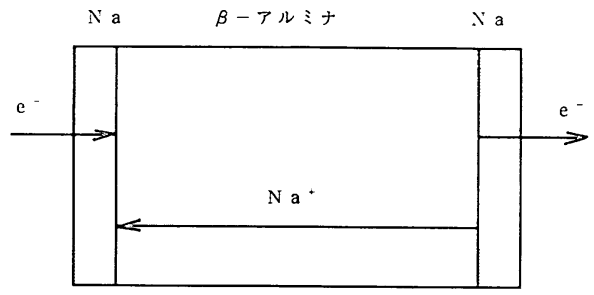

$\left(\mathrm{N} \mathrm{a}+\mathrm{e}^{-} \rightarrow \mathrm{Na}\right)$

$\left(X a \rightarrow a^{+}+e^{-}\right)$

(c)

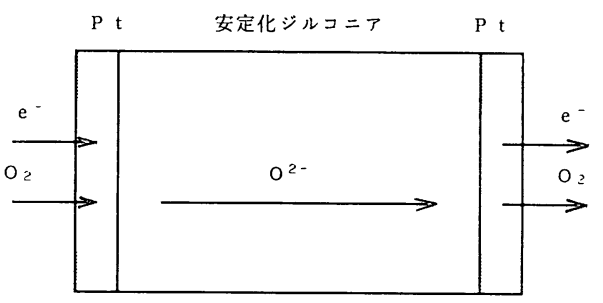

$\left(1 / 2 \mathrm{O}_{2}+2 \mathrm{e}^{-} \rightarrow \mathrm{O}^{2-}\right)$

$\left(\mathrm{O}^{--} \rightarrow 1 / 2 \mathrm{O}_{2}+2 \mathrm{e}^{-}\right)$

図 1 電子伝導体およびイオン（カチオン，アニオ ン）伝導体の電荷担体の流れ

(a) 電子伝導体/電極系

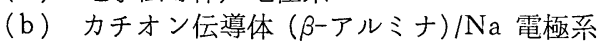

(c) アニオン伝導体 (安定化ジルコニア) $/ \mathrm{Pt}$ 電極系

亿紹介します。。

\section{2 安定化ジルコニアの応用}

酸化物イオン伝導体として安定化ジルコニアが注目さ れ, 隔壁として利用した電気化学的セルの起電力に対す る考察が報告1さされたのは，40 年前です。この原理に基 づくガスセンサは，1961 年に報告2)され，ますなく世界 中で酸素分析機器の心臓部として製品化されます。さら に, 自動車排出ガス浄化システムの中で, この形のセン サが注目され，大量に生産されるようになります。図 2 に示した三元触媒方式は, 昭和 53 年排気規制以来, 現 在まで市販されているガソリンエンジン乗用車の排気浄 化システムとして主流になっています。図 3(a)に示し た酸素センサは，てのシステムで排気の状態をモニタし 


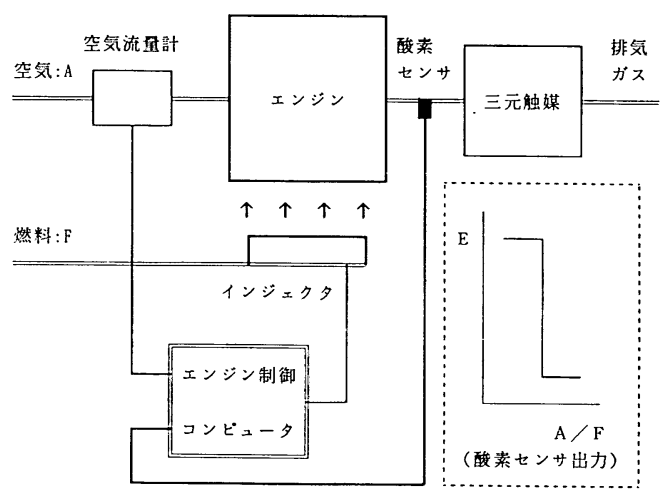

図 2 三元触媒方式自動車エンジン排気ガス浄化シ ステム

て空気と燃料の比を制御するのに不可欠です。ドイッで

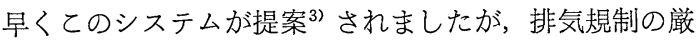
しい日本や米国で先に大量に生産されはじめました。

安定化ジルコニアは，七ンサのほかに高温型燃料電池 (SOFC : Solid Oxide Fuel Cell) の隔壁として研究が進 められています。図 3 (b) 亿電池の構成を示しました。

SOFC には，七ルの形状から一体型，円筒型求よび平 板型が考えられています。セルの基本構成は，いずれす 安定化ジルコニアをイオン伝導体として，その両側を空 気極と然料極が挟んだ形をとります。円筒型などでは， すでに，数 $\mathrm{kW}$ 規模のモジュールで稼働テストが繰返 されています。電極としては，ペロブスカイト型酸化物 や金属サーメットが検討されています。

$\mathrm{SOFC}$ は, 動作温度が $1,000^{\circ} \mathrm{C}$ 前後と高温で, 他の電 池より, (1)高出力密度で高い効率, (2)改質装置が不要, (3)高温の排熱を利用できる点で優れています。

\section{3 燃料電池の電極について}

困 3(a)と(b)を見比べて, SOFC は酸素センサと同 じイオン伝導体を使っているのに，なぜセンサでは白金 電極が使われ，SOFC では酸化物電極が検討されている のかむ疑問をおあちのととと思います。最む大きな違い は動作温度です。SOFC は常時 $1,000^{\circ} \mathrm{C}$ 前後で動作し, センサは平均して $500^{\circ} \mathrm{C}$ 前後で㗢きます。また， SOFC は大量の電力をエネルギーとして取り出すため, 効率よ く燃料と空気を反応させる必要があります。一方，セン サは微弱な電気信号を取り出す少量の反応ですみます。 センサ電極で第一に望まれるのは，SOFC の動作温度と 比べかなり低い温度, $500^{\circ} \mathrm{C}$ でも電極反応の触媒活性が 高いことです。

最後に，価格の問題があります。高温であ白金電極の 性能はたいへん優れていますが，動作中の白金蒸発量が 無視できません。SOFC では，プラントとして稼㗢さ せた場合に価格的に成立する電極材料の研究がなされ，
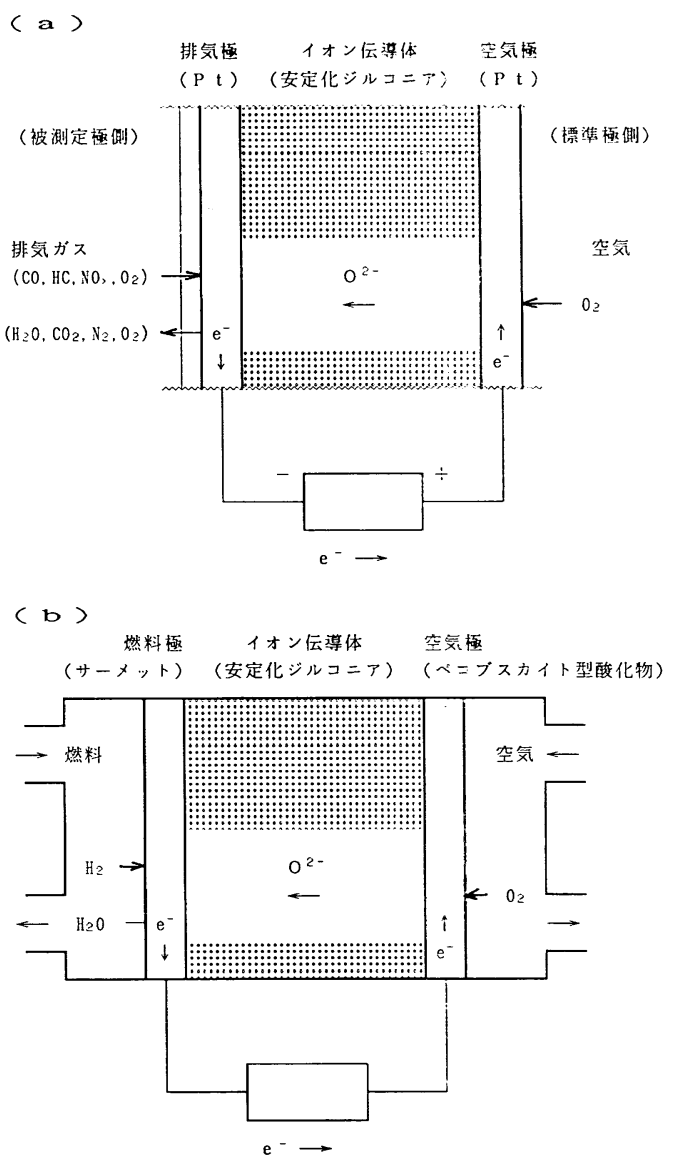

図 3 酸素センサおよび然料電池の原理図

(a) 酸素センサ

(b) 然料電池 (SOFC)

一連の探索から，ペロブスカイト型酸化物などが空気極 の候補として残ったわけです。

\section{4 酸素センサの電極について}

電極の開発が重要なのは, SOFC だけではありませ ん。センサの電極にむたくさんの工夫が詰め込まれてい ます。

図 4(a)に示したように，センサの排気極側電極は, 多孔性セラミックスで覆われています。てのコーティン グ層は，污れたガスが直接電極へ到達するのを防ぐだけ でなく，応答速度を調整する役割を担っています。電極

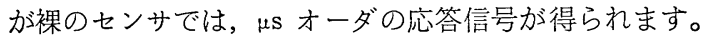
これは排気の瞬時でとの組成に応答したためです。エン ジン制御システムは，乙のような早い応答を必要としま せん。むしろセンサは，平均化したガス組成に対応す る，ms オーダの応答信号が得られれば制御に好都合で す。コーティング層の孔径，厚さなどはこの応答性と耐 久性の観点から詳細仾究4)されています。 


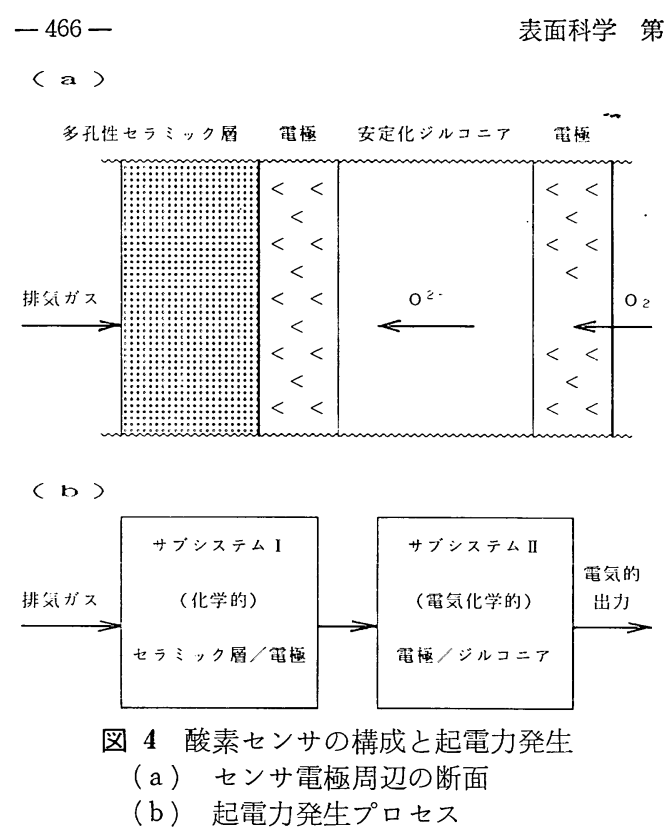

センサが図4（a）亿示したような構成で，起電力を発 生する過程を考えてみます。図 4 (b)は，Fleming ${ }^{5)}$ が 提示した起電力発生プロセスです。ガソリンがエンジン で然焼した後のガスには, $\mathrm{H}_{2} \mathrm{O}, \mathrm{CO}_{2}, \mathrm{~N}_{2}$ などのほかに $\mathrm{HC}, \mathrm{CO}, \mathrm{NO} x$ などが含まれます。ガスの組成は回転 数やエンジン負荷に応じてたえず変化しています。セン サ電極が裸のとき，てれらのガスとの接触で発生する起 電力は，信号というょりノイズに近い応答になります。 コーティング層を設けますと，ガスはこれを通る間に平 均化されます。そして, 電極に到達したガスでは, 起電 反応に対して平衡酸素分圧としての作用を考えればよく なります。事実, 両極間のこの酸素分圧による濃淡電池 の起電力を計算6) すると, 実際のセンサ出力とほぼ一致 するととが確かめられています。

\section{5 電極反応メカニズム}

図 1 ( c c)のように白金ガス電極では, 電荷担体となる 酸化物イオンは, 電極外部から供給された酸素分子がイ オン化したすのです。高温系においては, 電極内部で起 こるこのイオン化反応のメカニズムを解析するのは容易 でありません。ジルコニア系でも電極内での物質移動や 電荷のやり取り（電極反応過程）は，まだ完全に解明さ れていません。すなわち, 図1（c）の下部にカッコ内に 示した電極反応の速度は電極の材料, 性状, 周囲の雾囲 気および温度などに左右されます。多孔性白金電極で起 こる物質移動には, 体積拡散, 粒界拡散, 表面拡散そし て細孔内拡散が考えられます。そして, 気相の酸素分子 が図の左側電極内で活性化されてイオンとなる位置とし

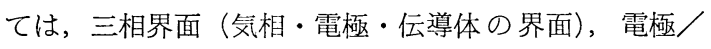
伝導体界面および伝導体内部が考えられています。一連
の反応プロセスについて, 律速となる過程が把握され, 活性化の位置むいずれ決定されると思います。そうなれ ば, 図 1,3 および 4 の中で電荷担体の流れを示す矢印 あむっと正確に示すととができます。

\section{4. おわりに}

電極の重要性をご理解いただくために，イオン伝導体 について, 安定化ジルコニア系を中心に紹介してきまし た。ジルコニアの機能素子への応用は進み, 酸素センサ などはエンジン制御に不可欠なるのとなりました。ての センサが実用化され，はや 15 年になります。しかし, 電極界面や電極表面での反応過程などの基礎的研究は, 触媒表面などでの研究に比べ大きく立ち後れています。 理由として高温系で使える測定手法に制約があり, 研究 者の絶対数が少ないととなどが考えられます。

イオン伝導体系以外にも，電極周辺に関心をむたれる 分野があります。たとえば，分析用イオン電極，医用電 極などは，それだけで一つの分野を占めています。本稿 ではふれられなかった興味ある現象が, 電極周辺にまだ たくさんあります。医学や生理学の分野では, 電極技術 の進歩》が細胞の㗢きについて新しい知見をむたらして います。また最近, 超 LSI の世界であ電極の研究 ${ }^{8}$ が注 目されています。サブミクロン, クォータミクロンデバ イスにおける微小電極の問題です。1988 年 11 月宝塚で 行われた第 2 回半導体の界面形成の国際会議, 日本学術 振興会半導体界面制御技術研究委員会 (第 154 委員会) 発足などは，乙の周辺に関する関心の増加を示すむので す。

イオン伝導体の電極について述べた本稿が，少しであ 表面および界面と電極のかかわりを理解するお役にたて ば幸いです。

\section{文献}

1) K. Kiukkola and C. Wagner: J. Electrochem. Soc. 104, 379 (1957).

2) J. Weissbart and R. Ruka: Rev. Sci. Instrum. 32, 593 (1961).

3) R. Zechnall, G. Baumann and H. Eisele: SAE Paper 730566, SAE Automobile Engineering Meeting, Detroit, May 14-18, (1973).

4) 内田清, 大久保禄治, 河合満雄 : トヨ夕技術 28 (1), 99 (1978).

5) W. J. Fleming: SAE Paper 800020 (1980).

6) D. S. Eddy : IEEE Trans. Veh. Tech. vt-23, 125 (1974).

7) E. Neher and B. Sakmann: Nature 260, 799 (1976).

8) 第 49 回応用物理学会学術講演会, シンポジウム 「金属一半導体 Si の界面形成と新しい評価法」 (1988). 